\title{
STUDIES ON THE EFFECTS OF
} SOME AGENTS ON FERTILIZED SEA URCHIN EGGS, AS A PART OF THE BASES FOR MARINE POLLUTION BIOASSAY I

\author{
$\operatorname{AUTHOR}(S)$ :
}

Kobayashi, Naomasa

\section{CITATION:}

Kobayashi, Naomasa. STUDIES ON THE EFFECTS OF SOME AGENTS ON FERTILIZED SEA URCHIN EGGS, AS A PART OF THE BASES FOR MARINE POLLUTION BIOASSAY I.

PUBLICATIONS OF THE SETO MARINE BIOLOGICAL LABORATORY 1973, 21(2): 109-114

\section{ISSUE DATE:}

1973-03-31

URL:

http://hdl.handle.net/2433/175805

RIGHT: 


\title{
STUDIES ON THE EFFECTS OF SOME AGENTS ON FERTILIZED SEA URCHIN EGGS, AS A PART OF THE BASES FOR MARINE POLLUTION BIOASSAY $I^{1)}$
}

\author{
NAOMASA KOBAYASHI \\ Biological Laboratory, Doshisha University, Kyoto
}

\section{Introduction}

The author examined the inhibitory degree of the polluted sea water in the Inland Sea of Japan upon the fertilization and further development of the sea urchin eggs (Kobayashi, 1972), after the manual of marine pollution bioassay proposed by him in 1971 (Kobayashi, 1971).

To supplement the previous two works on the one hand and to offer some more solid base for future works on the other hand, a few series of control experiments were made on four factors for marine pollution, which have not yet been dealt with in previou made on four factors for marine pollution, which have not yet been dealt with in previous papers; namely, tannic acid which can be the most significant pollutant derived from timber-reservoirs or lumber industry, the $\mathrm{pH}$ showing a side of acid or alkaline contamination, Kaolin which may be taken to show the effect of muddy water caused by reclamation or shed from denuded lands, and the thermal pollution which is met with generally around thermal power stations.

\section{Material and Methods}

Eggs of Anthocidaris crassispina (A. Agassiz) were experimented with in each test water to check the rate of fertilization, first cleavage, gastrulation and some anomalies in the development. Eggs were obtained by the current KCl-method, being washed several times with fresh sea water, and used as soon as possible, within 1 hour at the latest. Sperms were obtained from testes within 1 hour after being taken out of the test. The standard sperm density for insemination was maintained at about 1 dry sperm: 1,000 sea water in volume. When it was necessary, the preliminary check of eggs was done in the control laboratory water to see if the fertilization membrane was elevated in 3 minutes after insemination in over $85 \%$ of eggs and if the well synchronized first cleavage occurred in over $80 \%$ of them. The eggs were inseminated in respective test water within 2-3 minutes as far as possible. Firstly the percent of eggs with the elevated fertilization membrane to the total eggs observed was read. The first cleavage occurred in most cases 45 to 60 minutes after the insemination at

1) Contributions from the Seto Marine Biological Laboratory, No. 582.

Publ. Seto Mar. Biol. Lab., XXI (2), 109-114, 1973.

(Article 12) 
$26^{\circ} \mathrm{C}$ or $28^{\circ} \mathrm{C}$. Then, the rate and state of the first cleavage, namely proportions of undivided cells, normal two cells and multi-cells caused by polyspermy were checked at some adequate time. Two hundred eggs were fixed with $5 \%$ formaldehyde at a time for this examination. Lastly, the state of swimming embryos exclusive of those deposited on the bottom, namely proportions of permanent blastulae, normal gastrulae and abnormal exogastrulae, was checked 12 to 15 hours after the insemination. Two hundred embryos were fixed at a time for this check. The test was repeated over 3 times on different batches. The results representing typically are described. The experiments were done with tannic acid and kaolin on July 25, 1971 at about $26^{\circ} \mathrm{C}$ in water temperature and with $\mathrm{pH}$ and higher temperature on August 19,1971 at $28^{\circ} \mathrm{C}$ in water temperature. The state of Anthocidaris crassispina eggs could not be exactly uniform throughout the period from July to August, but the effect of respective factors could never be influenced significantly by the difference in the state of eggs in this period, because the normal fertilization and development of these eggs were confirmed in advance by control experiments mentioned above.

Tannic acid and kaolin to be tested were in the preliminary experiments diluted each into a series of solution by successive dilution by ten times of the original solution (chemicals $1: 10^{4}$ sea water). In these series was found first the gross concentration range of respective agents, in which some anomalies appeared on developing sea urchin eggs. Then further series of solutions by successive dilution by two times were made within the gross concentration range of respective agents to see their inhibitory effects in detail.

To see the effects of $\mathrm{pH}$ and higher water temperature a series of sea water of succesive grades of these factors were prepared on the bases of their usual ranges in the control laboratory sea water. Table 2 show the results of experiments.

\section{Results}

1. Tannic acid and Kaolin (Table 1)

In Table 1, the concentrations of these agents are given in the column A by the dilution of the original solutions (Sea water for dilution/original solution, in volume), and the same is expressed in the column $B$ by the absolute molecular concentration (exclusive of bound water). The maximal ineffectual and minimal effectual concentrations are given in ppm. At checking the fertilization membrane formation 3 minutes after the insemination, the formation of lower fertilization membrane was excluded. In some solutions, there were found some eggs in which no cleavage followed the formation of the fertilization membrane.

At higher concentrations of tannic acid, the fertilization never occurred, and all eggs remained as they were at the beginning of experiments. The lower the concentration was, the more the fertilization was recovered, till the following cleavages were regained to usual rates. The polyspermy did not appear. Permanent blastulae and some retardation in development occurred at higher concentrations, but not any exogastrulae.

In the original suspension of kaolin $\left(1: 10^{4}\right.$; average size of kaolin particles about 
Table 1. Effects of tannic acid and kaolin uopn the fertilization and development of Anthocidaris crassispina eggs. Date: July 25, 1971 . Test water temperature: $26^{\circ} \mathrm{C}$. Original solution, chemicals $1: 10^{4}$ laboratory sea water. The column A of "concentrations" shows the dilution of the original solution by the volume in-original solution 1 : volume of sea water; B shows the same dilution in the absolute molecular concentration.

\begin{tabular}{|c|c|c|c|c|c|c|c|c|c|c|}
\hline \multirow[b]{2}{*}{ Chemicals } & \multicolumn{2}{|c|}{ Concentrations } & \multirow{2}{*}{\begin{tabular}{|l|}
$\begin{array}{l}3 \mathrm{~min} . \\
\text { after } \\
\text { insem. }\end{array}$ \\
$\begin{array}{l}\text { Fertiliz. } \\
\text { membra. } \\
\text { form. \% }\end{array}$ \\
\end{tabular}} & \multicolumn{3}{|c|}{$\begin{array}{l}60 \text { min. after } \\
\text { insemination }\end{array}$} & \multicolumn{3}{|c|}{$\begin{array}{l}15 \text { hrs. after } \\
\text { insemination }\end{array}$} & \multirow{2}{*}{$\begin{array}{l}\text { Ultimate } \\
\text { state of eggs }\end{array}$} \\
\hline & $\mathrm{A}$ & 1 & & $\begin{array}{c}1 \text { cell } \\
\text { state } \\
\%\end{array}$ & $\begin{array}{l}2 \text { cell } \\
\text { state } \\
\%\end{array}$ & \begin{tabular}{|l}
$\begin{array}{l}\text { Multi- } \\
\text { cells: } \\
\text { polysp. } \\
\%\end{array}$ \\
\end{tabular} & $\begin{array}{l}\text { Perma . } \\
\text { blast. } \\
\%\end{array}$ & $\begin{array}{c}\text { Norm. } \\
\text { gast. } \\
\%\end{array}$ & $\begin{array}{l}\text { Exo- } \\
\text { gast. } \\
\%\end{array}$ & \\
\hline Control sea water & & & 86 & 16 & 84 & 0 & 1 & 99 & 0 & normal \\
\hline \multirow{4}{*}{$\begin{array}{l}\text { Tannic acid } \\
\mathrm{C}_{76} \mathrm{H}_{52} \mathrm{O}_{46} \\
\text { min. eff.. conc.: } \\
\quad 6.3 \text { ppm } \\
\text { max. ineff. } \\
\text { conc.: } 3.1 \text { ppm }\end{array}$} & 4 & $16 \times 10^{-6}$ & 0 & 100 & & & & & & \multirow{4}{*}{$\begin{array}{l}\text { no fertilization } \\
\text { development } \\
\text { retarded } \\
\text { development } \\
\text { retarded } \\
\text { normal }\end{array}$} \\
\hline & 8 & $8 \times 10^{-6}$ & 26 & 85 & 15 & 0 & 18 & 82 & 0 & \\
\hline & 16 & $4 \times 10^{-6}$ & 53 & 49 & 51 & 0 & 1 & 99 & 0 & \\
\hline & 32 & $2 \times 10^{-6}$ & 85 & 17 & 83 & 0 & 0 & 100 & 0 & \\
\hline Kaolin & 0.1 & $4 \times 10^{-3}$ & 35 & 67 & 33 & 0 & 2 & 98 & 0 & $\begin{array}{l}\text { development } \\
\text { retarded }\end{array}$ \\
\hline $\begin{array}{r}\mathrm{H}_{2} \mathrm{Al}_{2} \mathrm{Si}_{2} \mathrm{O}_{8} \cdot \mathrm{H}_{2} \mathrm{O} \\
\text { min. eff. conc.: } \\
500 \text { ppm }\end{array}$ & 0.2 & $2 \times 10^{-3}$ & 48 & 55 & 45 & 0 & 1 & 99 & 0 & $\begin{array}{l}\text { development } \\
\text { retarded }\end{array}$ \\
\hline $\begin{array}{r}\text { max. ineff. conc.: } \\
250 \mathrm{ppm}\end{array}$ & 0.4 & $10^{-3}$ & 87 & 15 & 84 & 1 & 1 & 99 & 0 & normal \\
\hline
\end{tabular}

$1 \mu$ in diameter), did not appear any inhibitions in the fertilization and subsequent development. Moreover, at concentrations highe than $1: 10^{3}$ no observation was allowed to learn in what state the treated eggs were. As the turbidity was as high as 324 even at $1: 10^{3}$. Then, the suspension of $1: 10^{3}$ was diluted by successive dilution by two times. At the concentrations over $1: 4 \times 10^{3}$, rates of fertilization and subsequent cleavages were more or less reduced but the poyspermy did not appear. With the increase in concentration, later developmental stages were more or less retarded.

2. $\mathrm{PH}$ and higher temperature (Table 2)

The $\mathrm{pH}$ of the sea water was raised or lowered by addition of respectively caustic soda and hydrogen chloride, and checked by colorimetry. The $\mathrm{pH}$ of the control running sea water of the laboratory (7.8) was a little lower than that of the open sea water (8.2-8.3). With the decrease of $\mathrm{pH}$, rates of fertilization and subsequent cleavages were reduced, and the treated eggs remained as they were at the beginning of experiments. At $\mathrm{pH} \mathrm{7,} \mathrm{the} \mathrm{fertilization} \mathrm{occurred} \mathrm{on} \mathrm{most} \mathrm{eggs,} \mathrm{but} \mathrm{almost} \mathrm{poly-}$ spermic, and the cleavage ceased at earlier states. In the range from 7.8 to 8.6, the fertilization, cleavages and further development appeared to be carried out normally. With the increase of $\mathrm{pH}$ over 8.6, rates of fertilization and subsequent cleavages decreased, and the cytolysis occurred at earlier stages.

The temperature experiments were made in two series of different temperature degrees; this was not intended but due to the thermostat used. With the raise of temperature, rates of fertilization and subsequent cleavages were reduced, while the formation of multi-cells by polyspermy was promoted and thus the cytolysis occurred 
Table 2. Effects of $\mathrm{pH}$ and higher temperature upon the fertilization and development of Anthocidaris crassispina eggs. Date: July 28 and August 19, 1971. Test water temperature: $28^{\circ} \mathrm{C}$.

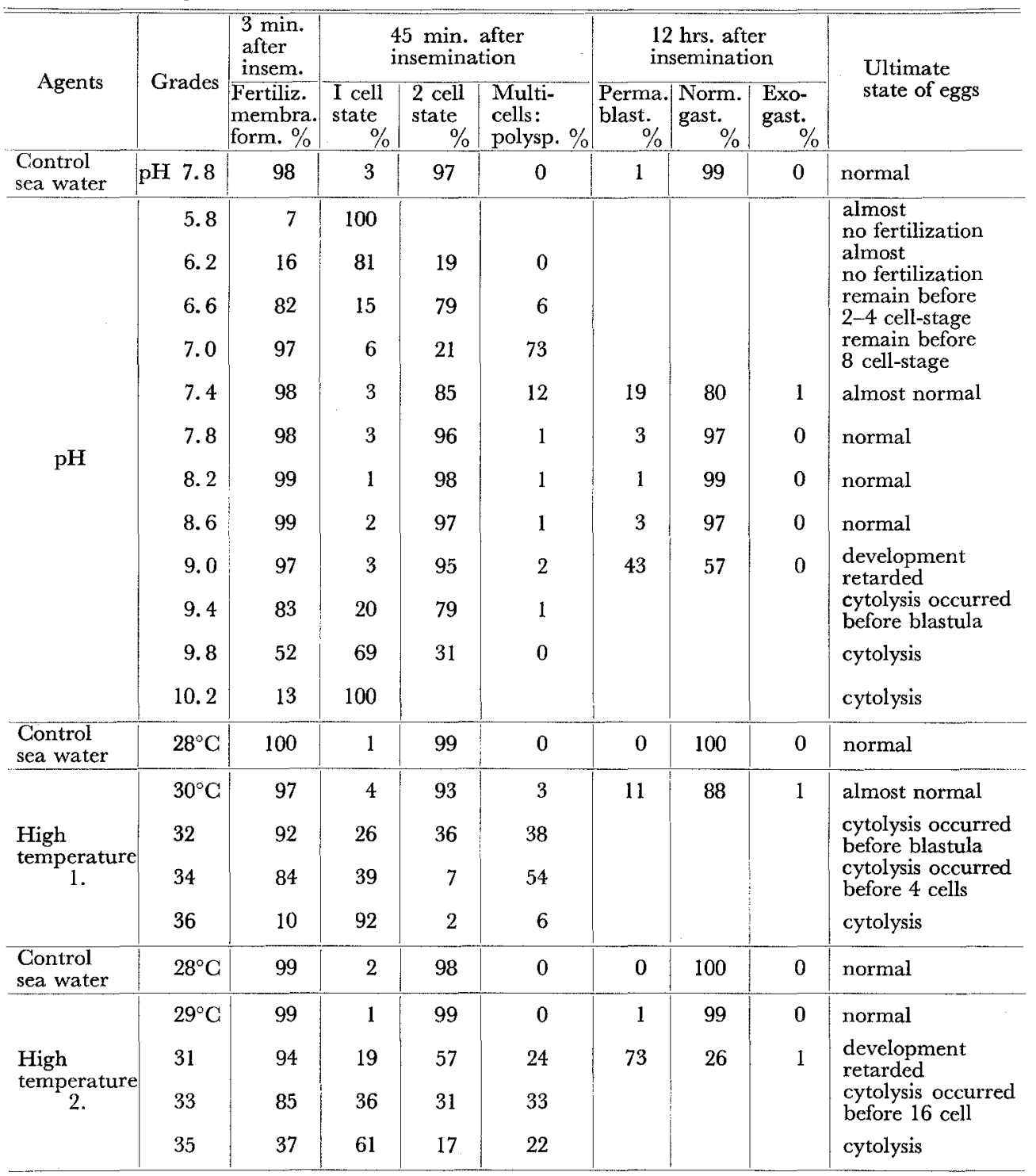

at earlier states. Another test indicated that the fertilization did not occur at higher temperature over $37^{\circ} \mathrm{C}$.

\section{Considerations}

It is obvious that various pollutants affect differently at different developmental stages of sea urchin eggs at different concentrations (Kobayashi 1971).

The inhibitory effects of the turbid water along the northern coast of Tanabe 
Bay, i.e. the water from Mori and Egawa Harbours, upon the fertilization and development of sea urchin eggs are seemingly attributable to tannic acid derived from the timber reservoir and deposited bark pieces in the sea areas. A similar phenomenon was suggested by Tabata (1956) who supposed that tannins was the main toxic components of extracts from timbers stored in the sea. The minimal concentration of tannic acid to inhibit the fertilization, cleavages and further development of sea urchin eggs was $6.6 \mathrm{ppm}$, this concentration coincides almost with that given in the paper of Okubo and Okubo (1962) reporting a bioassay for the sea water pollution using developing eggs and embryos of sea urchins and bivalves. Further, it must be noted that the toxicity of tannins is comparable to that of chrome and manganese and much stronger than that of waste oil.

The effects upon marine organisms of muddy water derived from various sources have not yet been studied fully, though the effects will differ according to the nature of substances, size of particles, and their density. Thus, the effect of kaolin, the main component of clayey soil, upon the sea urchin eggs was observed. The suspension of pure kaolin washed by acid and consisting of particles ca. $1 \mu$ in diameter is neutral, non poisonous, in a state of hydrosole and adsorptive of some ions or large molecules in the sea water. At the concentrations over $250 \mathrm{ppm}$, the fertilization, cleavages and later development were more or less affected. Possibly the clayey muddy water, as well as the suspension of kaolin, may affect the respiration and surface charge etc. of eggs of marine animals or the condition of the sea water, or simply adhesion of particles on the egg or embryo surface may induce sinking of them down to the seafloor that must be their grave.

The normal fertilization and cleavages are maintained in Anthocidaris crassispina between $\mathrm{pH} 7.8$ to 8.6 , but the decrease of $\mathrm{pH}$ below 6.6 will reduce the rate in fertilization and subsequent cleavages. Polyspermy is induced at neutral pH. The increase of $\mathrm{pH}$ over 9.0 also reveals the reduction in rates of fertilization and cleavages, followed by cytolysis. It has been noted since many years ago that the sea water of lower or higher $\mathrm{pH}$ is unavailable to secure the normal fertilization and development of sea urchin eggs. It was observed with Arbacia by Smith and Clowes (1924) that the fertilization was blocked below $\mathrm{pH} 6.8$ and above 10.0, normal cleavages (if fertilized in sea water) maintained at 5.8 to 8.2 , but were retarded below 5.2 and above 9.4, the maximal polyspermy appeared near 7.2 (also by Clark 1936) and the greatest cytolysis occurred above 9.3. Throughout the results of the present experiments and those obtained by previous researchers, the normal fertilization and development of sea urchin eggs seem to be maintained in the range from $\mathrm{pH} 7.4$ to 8.6. This range seemingly coincides fairly with the $\mathrm{pH}$-range allowing the normal reproduction of marine fishes, etc.

With the raise of temperature, rates of fertilization and cleavages will be reduced, while polyspermy and cytolysis will be increased. There have been made many experiments with higher temperature to induce such anomalies in the fertilization and further development of sea urchin eggs as inhibition of cleavage (Hoadley and Brill 1937), polyspermy (O. and R. Hertwig 1887) and cytolysis (Dan 1936, etc.). 
All these results seem to indicate that the temperature higher by over 3 degrees centigrade than the usual summer water temperature may affect considerably the reproduction of marine organisms.

The author wishes to express his hearty thanks to the staff of the Seto Marine Biological Laboratory for a fund and the facilities given to him in carrying out the researches at the laboratory, particularly to Dr. Takasi Tokioka of the Laboratory for advices and criticisms and also for his kindness in reading the manuscript.

\section{Summary}

1. A few series of experiments were made to clear the effects of four factors for marine pollution, tannic acid, kaolin, $\mathrm{pH}$ and higher temperature, after the manual of bioassay using sea urchin eggs and embryos (Kobayashi, 1971).

2. The minimal concentration of tannic acid, the main toxic component of the extracts from timbers stored in the sea, to inhibit the fertilization, cleavage and later development of sea urchin eggs was $6.3 \mathrm{ppm}$.

3. Kaolin, the main component of clayey soil, at the concentrations over $250 \mathrm{ppm}$ more or less affected the fertilization, cleavage and later development.

4. The normal fertilization and cleavages were maintained in Anthocidaris crassispina between $\mathrm{pH} 7.8$ to 8.6 , the neutral $\mathrm{pH}$ remarkably induced polyspermy, the decrease of $\mathrm{pH}$ below 6.6 reduced rates of fertilization and cleavage, and the increase of $\mathrm{pH}$ above 9.0 also brought about the reduction in fertilization and cleavage rates followed by cytolysis.

5. The raise of temperature by more than 3 degrees Centigrade above the usual summer water temperature reduced rates of fertilization and cleavage, but promoted polyspermy and cytolysis.

\section{REFERENCES}

Clark, J. M. 1936. An experimental study of polyspermy. Biol. Bull. 70: pp. 361-384.

Dan, K. 1936. Electrokinetic studies of marine ova. III. The effect of dilution of sea water, and of sodium and calcium upon the surface potentials of Arbacia eggs. Physiol. Zool. 9: pp. 43-57.

Hertwig, O. and R. 1887. Über den Befruchtungs- und Teilungs-vorgang des tierischen Eies unter dem Einfluss äusserer Agentien. Jena. Zeitsch. N.F. 13: pp. 120-241 and 477-510.

Hoadley, L. and Brill, E. R. 1937. Temperature and the cleavage rate of Arbacia and Chaetopterus. Growth 1: pp. 234-244.

Kobayashi, N. 1971. Fertilized sea urchin eggs as an indicatory material for marine pollution bioassay, preliminary experiments. Publ. Seto Mar. Biol. Lab. 18: pp. 379-406.

Kobayashi, N., Nogami, H. and Doi, K. 1972. Marine pollution bioassay by using sea urchin eggs in the Inland Sea of Japan (the Seto-Naikai). Publ. Seto Mar. Biol. Lab. 19: pp. 359-381.

Okubo, K. and Okubo, T. 1962. Study on the bioassay method for the evaluation of water pollution II. Use of the fertilized eggs of sea urchins and bivalves. Bull. Tokai Reg. Fish. Res. Lab. 32: pp. 131-140.

Smith, H. W. and Clowes, G. H. A. 1924. The influence of hydrogen ion concentration on the fertilization process in Arbacia, Asterias and Chaetopterus eggs. Biol. Bull. 47: pp. 333-344.

Tabata, K. 1965. Systematic studies on toxic components in industrial wastes with reference to the tolerance of aquatic lives-III. On acute toxic components in water-extract liquor from bark. Bull. Tokai Reg. Fish. Res. Lab. 42: pp. 17-21. 